\title{
Effective or not? Success or failure? Assessing heritage and archaeological education programmes - the case of Çatalhöyük
}

\author{
Veysel Apaydin \\ Department Culture, Communication and Media, Institute of Education, University College \\ London, London, United Kingdom.
}

To cite this article: Veysel Apaydin (2016): Effective or not? Success or failure? Assessing heritage and archaeological education programmes - the case of Çatalhöyük, International Journal of Heritage Studies, DOI: 10.1080/13527258.2016.1218912

\begin{abstract}
Recent decades have witnessed an increasing involvement of archaeology projects in planning and carrying out heritage education programmes to increase heritage awareness among the public. This paper aims to explore ways in which models of education programmes in public archaeology could be more effective in ensuring the protection of heritage sites by examining the one of the worlds longest-running education programme, run by the Çatalhöyük Research Project in Turkey. It is important to pay attention to multi-vocal elements such as social, political and educational backgrounds of the communities to develop more effective education programmes, and most importantly it is crucial to assess the effectiveness and success of those programmes. However, most of archaeological education programmes have failed to carry out this important component. In order to be effective and successful, the success of the education programmes and the ways in which they are implemented and their results must be known and critically examined. Specifically, this paper will discuss the necessity of measuring the effectiveness of education programmes, suggest the most suitable methodology for assessment through examining the Çatalhöyük education programmes.
\end{abstract}

\section{Introduction: why do heritage and education matter?}

Over the last few decades, community engagement within the heritage sector has increased substantially and has gone through transformation in terms of research and methodologies. Additionally, recent studies have focused on how formal education can reach large numbers of people (Planel 1994; Copeland 2004; Corbishley 2004; Henson 2004a, 2004b; Apaydin 2015, forthcoming-a). Researchers argue that heritage related subjects have been neglected in comparison with other subjects. The oversimplification and undermining of archaeology and heritage subjects in formal education is a more or less global phenomenon. Although the quality of, and time spent on, the teaching of archaeology and heritage has increased in some countries, such as the United Kingdom and some other European countries, students still need to have a 'hands on' relationship with archaeology and heritage. This means not only informing people about local heritage but also giving them opportunities to see, touch and feel archaeology and heritage objects, which can increase the interest of people towards their local heritage. An example of this is the Shoreditch Park Community Project, which allows community members access to all stages of the project from 'research to excavation and process[ing] of the finds' (see Simpson 2011, 115). 
This 'hands-on' experience is often referred to as 'informal archaeological education, community education, or public and community archaeology' (for definitions see Moshenska and Dhanjal 2011), and it is this aspect of heritage studies that should be given more importance and care. It should become a standard part of archaeological projects and education programmes of any museum or heritage body, particularly if heritage or education specialists aim to increase heritage awareness among the public.

In the UK, public archaeology is perhaps given more attention compared to other parts of the world. For instance, the 'Young Archaeologists Club', which was established in the 1970s and has expanded to several cities, involves teachers, archaeologists, museum educators or curators, and aims to increase the public accessibility of archaeology and heritage (see Dhanjal 2008; Henson 2011). Another good example is the work of Museum of London, which works with London schools to introduce archaeology and heritage to pupils with the aim of encouraging better protection and preservation of archaeological sites and heritage.

However, most of the community education programmes have neglected to assess their effect on the public; that is whether these programmes have succeeded in increasing heritage awareness among communities. Have the perception and attitudes of public towards heritage changed in a positive way? In order to judge the success of education programmes, projects should measure their impact at intervals, and change them according to the needs of communities and to improve their effectiveness. This is particularly important for education projects that work with children.

There are many issues in working with children, including the different learning abilities and understanding of the past of children whose physical and personal development (Falk and Dierking 2000, 11; Falk 2005, 266), motivation, age, interest and cognitive development (see Davis 2005) are different. Most children perceive the past according to their socio-political backgrounds and, most importantly, as individuals of the society, they interpret and value the material culture of the past as part of political ideology (Smith 2006, 2010, 2012) that is largely learned from formal education (Apaydin 2016). In other words, political use of past greatly affects the valuing of the material culture of the past (Smith 2006) The interpretation of heritage in Turkey provides a good example of the topdown approach, which prevents interactive learning possibilities of children (Apaydin 2016).

The results of this research indicate another problematic issue: that of one-day heritage education programmes. These involve short visits to archaeological sites, whose cultural contexts are completely different to those of the children visiting. For example, in the case of communities around Çatalhöyük, children come from very conservative, Islamic and nationalist contexts (Candan 2007; Apaydin 2015), which shape their worldview and values. Çatalhöyük is a Neolithic site that has no connection to communities' values. Therefore, a oneday trip to the archaeological site is not sufficient enough for the children to develop a deep understanding of the importance of this internationally significant site.

In view of the problems with heritage education in Turkey, this paper will address the importance of assessing long-term heritage education programmes, in terms of their effectiveness and assessment methodologies. This paper will also discuss how to design effective and successful heritage education programmes, using the Çatalhöyük Education Programmes as a case study. First, a brief overview of Çatalhöyük and its communities will be given; second the methodology of the research is detailed; and third, the results of the study 
will be discussed. Finally, I will conclude with a discussion that will address the broader question: 'How can archaeological education programmes be effective?'

\section{Çatalhöyük: a Neolithic site}

Çatalhöyük is located on the Konya plain of south central Turkey, about $50 \mathrm{~km}$ from the city centre of Konya. It is surrounded by a scatter of modern villages, the nearest being Küçükköy (Figure 1). Çatalhöyük was first excavated between 1960 and 1965 by the British scholar, James Mellaart. It quickly became an internationally important site because of its size, complex structure and status as one of the earliest Neolithic sites outside the Fertile Crescent. However, it was discovery of the unique characteristics of the site, such as sculpture and paintings on the walls of the houses, which made it even more famous. James Mellaart suggested that the special art and other unique features were indicative of the complex social and political organisation of the settlement (see Mellaart 1967). The excavations ceased in 1965.

British archaeologist Ian Hodder restarted excavations in 1993 and has led the campaign since then with an international team (see Hodder 1996, 2000a). However, in contrast to the Mellaart excavations, Hodder and his team have not only focused on the excavations but also on regional surveys, conservation, public archaeology and educational programmes, whose aims include listening and learning from other people (see Hodder 2000a, 2000b).

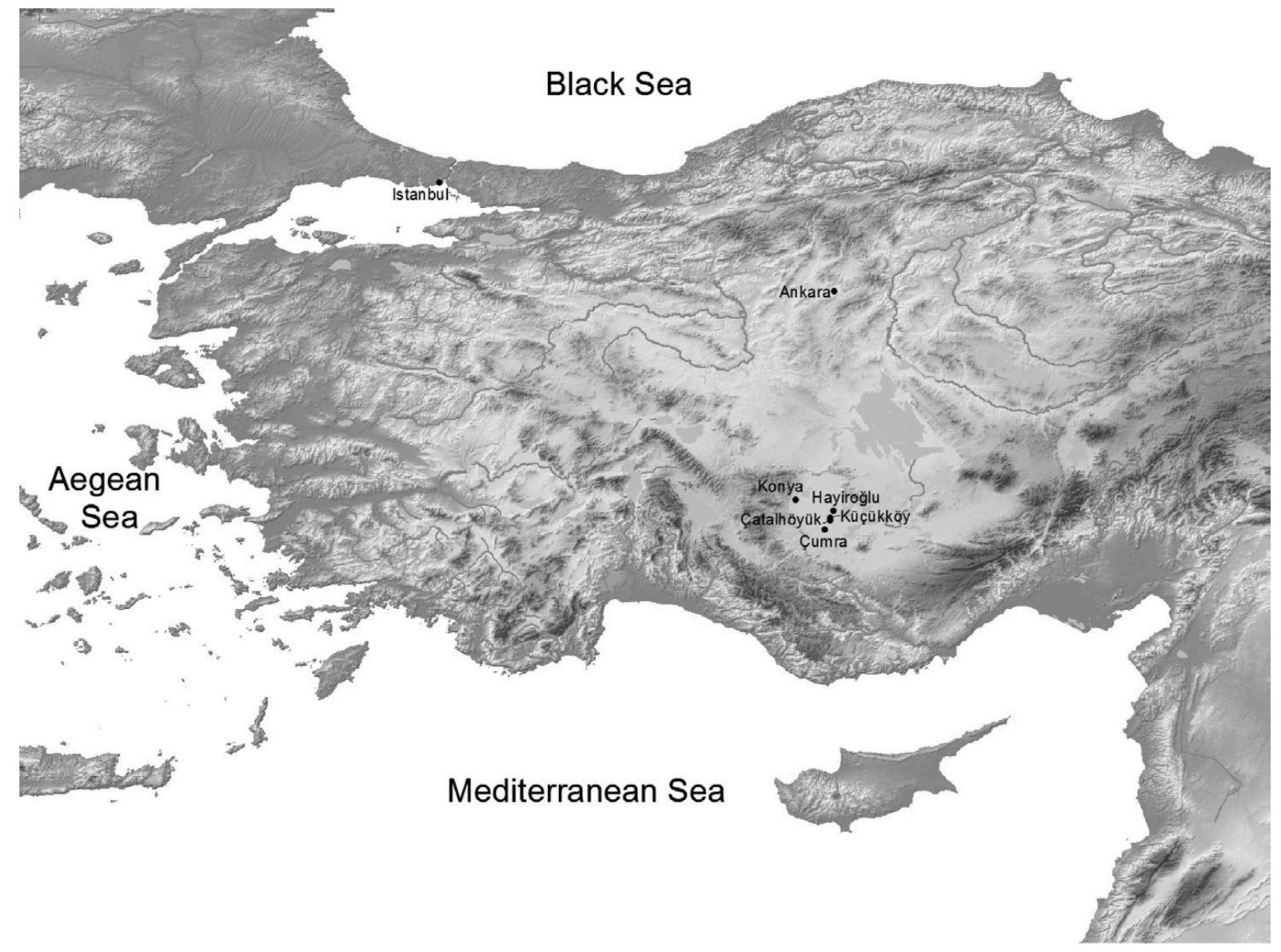

Figure 1. Location of Çatalhöyük and surrounding communities. 


\section{The communities of Çatalhöyük: social, political and educational structure}

The village of Küçükköy, populated by 695 people, Hayıroğlu, populated by 1250 people, and the town of the Çumra, populated by 42,308 people, are the nearest modern settlements to Çatalhöyük. These three settlements are conservative and also nationalist in character (see Candan 2007, 96; Apaydin, forthcoming-b). The social structures of the villages are also shaped by Islamic tradition, as is the whole region of Konya (see Shankland 1999, 2004), with a heavy presence of religion and strict practice of religious days such as Ramadan. Gender roles and the structure of the families are also influenced by Islamic tradition. Men always have priority, as in most of the conservative villages in Turkey. The roles of women are usually limited to looking after children and housework. The level of education in the area is generally low. Because of the low levels of education and because most people have little or no access to knowledge of their local heritage, the importance of heritage educational programmes increases substantially.

The economies of Konya and Çumra, Küçükköy and Hayıroğlu villages are dependent on farming, and a large percentage of Turkey's wheat and other agricultural products are produced in this region. Tourism and industry are not developed in this area, although there is potential in Konya for tourism because of its important religious sites (see Keskin and Önen 2012). Küçükköy has also benefitted from the Çatalhöyük Research Project as it employs a large number of workers from the village (the excavation season used to run for 4-5 months each year). Another important contribution of these excavations to Küçükköy was to employ women on the project. However, in the last few years, the numbers of employed workers have been reduced and today only 10 to 20 villagers work on the project, for a shorter period of time. This has decreased the relative monetary importance of the project for the village.

\section{Methodological approach: measuring effectiveness}

The main aim of the research was to measure the effectiveness or impact of the current education programme at Çatalhöyük that is the programme has been successful, has positively whether influenced individuals' heritage perspectives, has increased the archaeological and heritage knowledge of the participants and, most importantly, has improved the heritage awareness of participants after taking part in the education programmes. Measuring this effectiveness of heritage research education programmes was a unique and challenging opportunity because this sort of research is not common in archaeology and heritage studies. Therefore, I expanded into different fields, besides archaeology and heritage, in order to find similar examples of this type of assessment, including: museum-based learning (Hein 1998; Holmes 2011), museum experiences (Piscitelli and Anderson 2001); experience of children in heritage sites (Tzibazi 2014); learning in education (Brown, Bull, and Pendlebury 2013) and assessment of field trips (Falk and Dierking 1997; Nadelson and Jordan 2012).

Specific questionnaires designed to measure the effectiveness of the programme. The questionnaires were in Turkish, written in such a way as to be easily understood by all participants in the survey. I also consulted with academics who specialise in the pedagogy of children. Additionally, before participants received the questionnaires, I explained all questions in detail and I made sure they understood everything clearly. In order to avoid losing detail, 
accuracy and nuance of the participants' points, I analysed and interpreted the answers in Turkish, before translation into English.

The questionnaires provided a unique opportunity to assess the long-term results of the archaeological education programmes. This, however, introduced another question: "What methodology is best to assess the education programmes?' This was the most difficult challenge for me as there was no prior literature or assessment done on this project with regards to education and outreach.

All groups of children were chosen randomly from available schools; the education programme hadn't selected people based on interest in archaeological work, history, heritage or participation in the education day. This not only limited the effectiveness of the education programme but also limited my survey as there was no information about children's selections. Therefore, I had no choice but to select an experimental group randomly from available children in nearby villages.

In the first stage, archival research determined who and how many people had attended the programmes, as well as their current locations. Thirty participants who took part in the Çatalhöyük education programmes between seven and ten years ago were found. They still live in villages close to Çatalhöyük. This group became the 'experimental group' and a separate questionnaire was designed for them. Their socio-political backgrounds were clarified through unstructured interviews before the designing and distribution of the questionnaires. Questions were asked regarding their general archaeological and heritage knowledge, their heritage perception, and their specific and general knowledge of Çatalhöyük.

However, the question of how to measure the effectiveness was still an issue. In order to overcome this obstacle, another thirty people from the same village, who were of similar age and socio-political and educational backgrounds as the experimental group, but who had never attended any of the education programmes, were asked to do the survey. A questionnaire was designed for this 'control group'. Questions were again about general archaeological and heritage knowledge, their heritage perceptions, and about their specific and general knowledge of Çatalhöyük.

The questionnaires were designed so that every single individual question was relevant, appropriate, precise, and as far as possible, unbiased. Question types were both 'closed and open' (for more information regarding closed and open questions see Oppenheim 1992). In the closed questions, the subject is presented with simple answer choices, or tick-box responses; however, open questions did not have limitations on answers. Since closed and open questions were used, both quantitative and qualitative methods were employed for analysing the questionnaires. Analysis of the answers of the control group provided the opportunity for comparison with the experimental group in order to assess the effectiveness of the education programme.

\section{Çatalhöyük education programme}

The education programme at Çatalhöyük is one of the world's longest-running informal archaeological education programmes. It started with a pilot education programme that was run during the 2002 and 2003 seasons by the TEMPER project (see Hodder and Doughty 2007). The programme has since been run without interruption every excavation season. The aim of the programme is described as follows: 'to develop heritage awareness and teaching the 
importance of the protection of heritage and cultural sites and presenting issues of protection of heritage sites by introducing Çatalhöyük as a case study' (Çatalhöyük Archive Report 2011). The length of programme was typically four weeks for every field season and different groups of children from different schools arranged to come to the site to attend to education programmes.

The programme takes place during summer time, during the excavation season and when schools are closed, therefore, it is an informal learning opportunity during the children's vacation time. The programme is not part of a school curriculum. Teachers from the schools accompany the children during the education day; however, they are not involved with the education programme itself. The programme is run by an archaeologist and developed using the 'top down' approach. Throughout the design of the programme, there was no local community involvement, nor was there input from educators. The ages of the children range from eight to fourteen. The number of children who attend education day is usually around twenty a day. Approximately five hundred students attend each year (Çatalhöyük Archive Report 2011) and approximately five thousand children have attended since it started over ten years ago. The programme also occasionally organises education days for adults as well.

During the education day, the children are given an introductory lecture about Çatalhöyük with a slide show, then they are taken on a visit to the experimental house (replica of Çatalhöyük Neolithic house), the site, and then to a workshop where children can make imitations of the clay objects or paintings (Figures 2 and 3 ).

\section{Experimental group: participants who attended the education programme}

In total, thirty participants from the experimental group completed the questionnaire. The gender breakdown of the group was 12 males and 18 females. The participants of experimental group visited the site between 7 and 10 years ago; current ages of the participants ranged between 18 and 20 at the time of the survey. The education levels of the experimental group range from primary school to university (Figure 4).

Interestingly, the majority of people who took part in the education programmes emphasised that they had no intention of attending the education programme but that it was a compulsory activity of their school even though education day takes during the summer time when schools are closed. Most of them also pointed out that they had no knowledge about archaeology, heritage, or Çatalhöyük before participating in the education programme. The main reason for this is that the Turkish formal education system has largely neglected archaeology and heritage topics that are not related to ethnic Turkish and Islamic history (Apaydin 2016). Additionally, levels of informal education by museums or NGOs are quite low in Turkey compared to western countries such as the UK or US (Apaydin 2015). Therefore, other than internet sources, participants had no other alternative information sources, such as libraries or nearby museums where they could find information on archaeology, heritage and Çatalhöyük. 


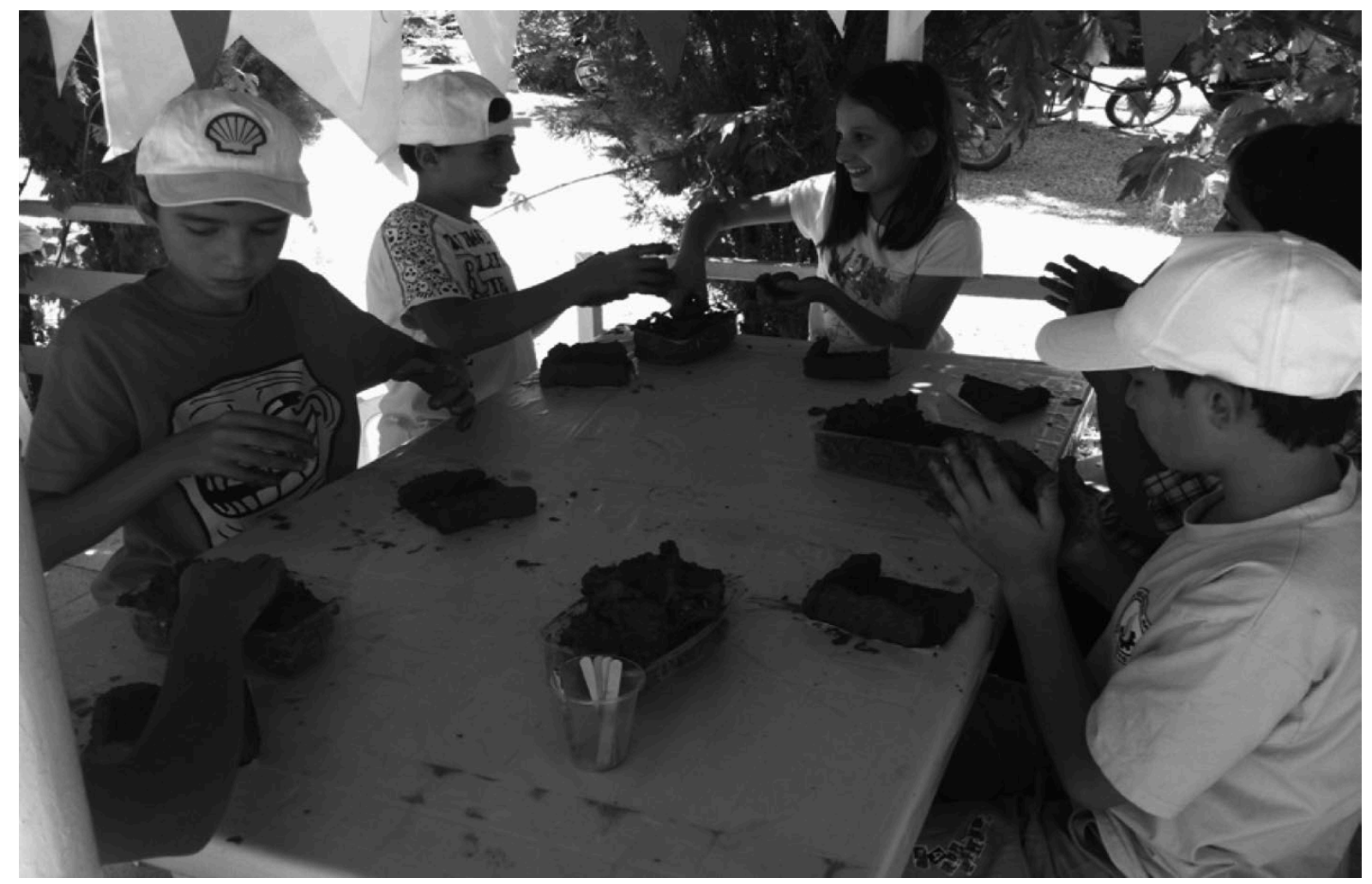

Figure 2. Making clay objects.

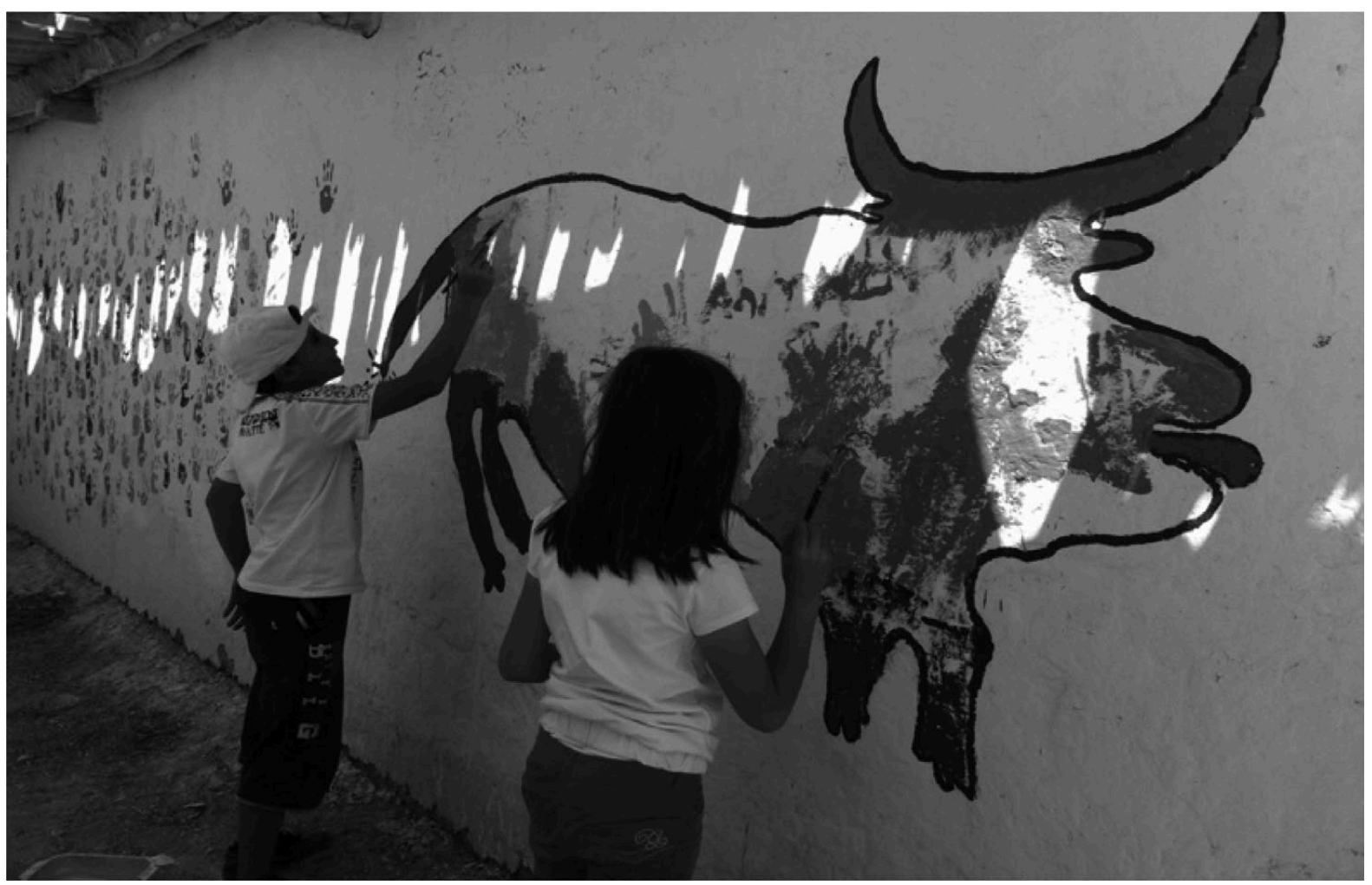

Figure 3. Painting of bulls during the education programme.

The first four close-ended questions of the questionnaire aimed to measure basic knowledge of the participants regarding the archaeology that had been taught at the education day to participants: (1) What is archaeology? (2) How are archaeological sites found? (3) What do archaeologists look for? (4) Why do archaeologists examine the remains of the past? Although 
questions were quite basic and could be answered with general knowledge, most of participants failed to answer the questions correctly (Figure 5).

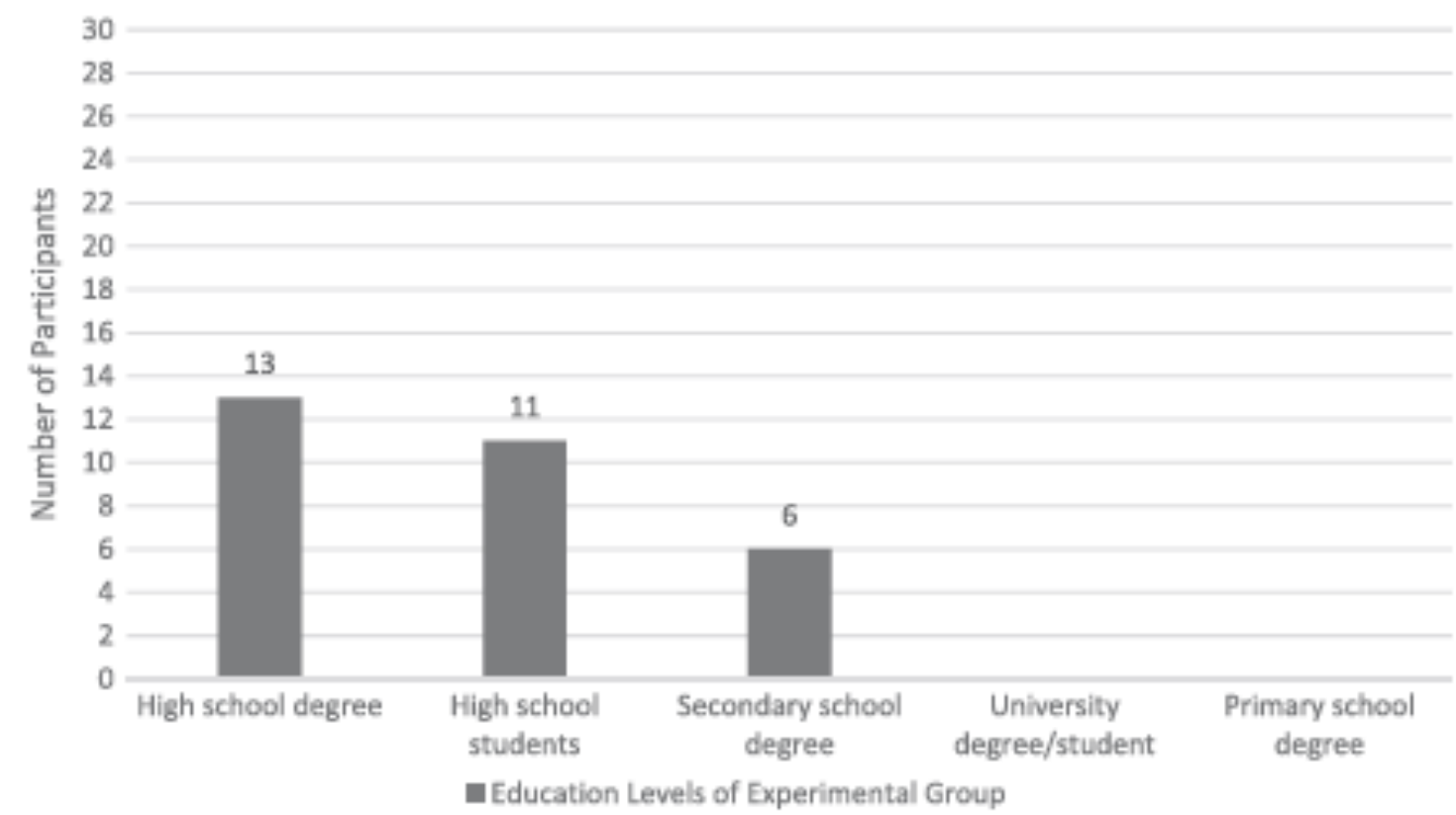

Figure 4. Education levels of the experimental group.

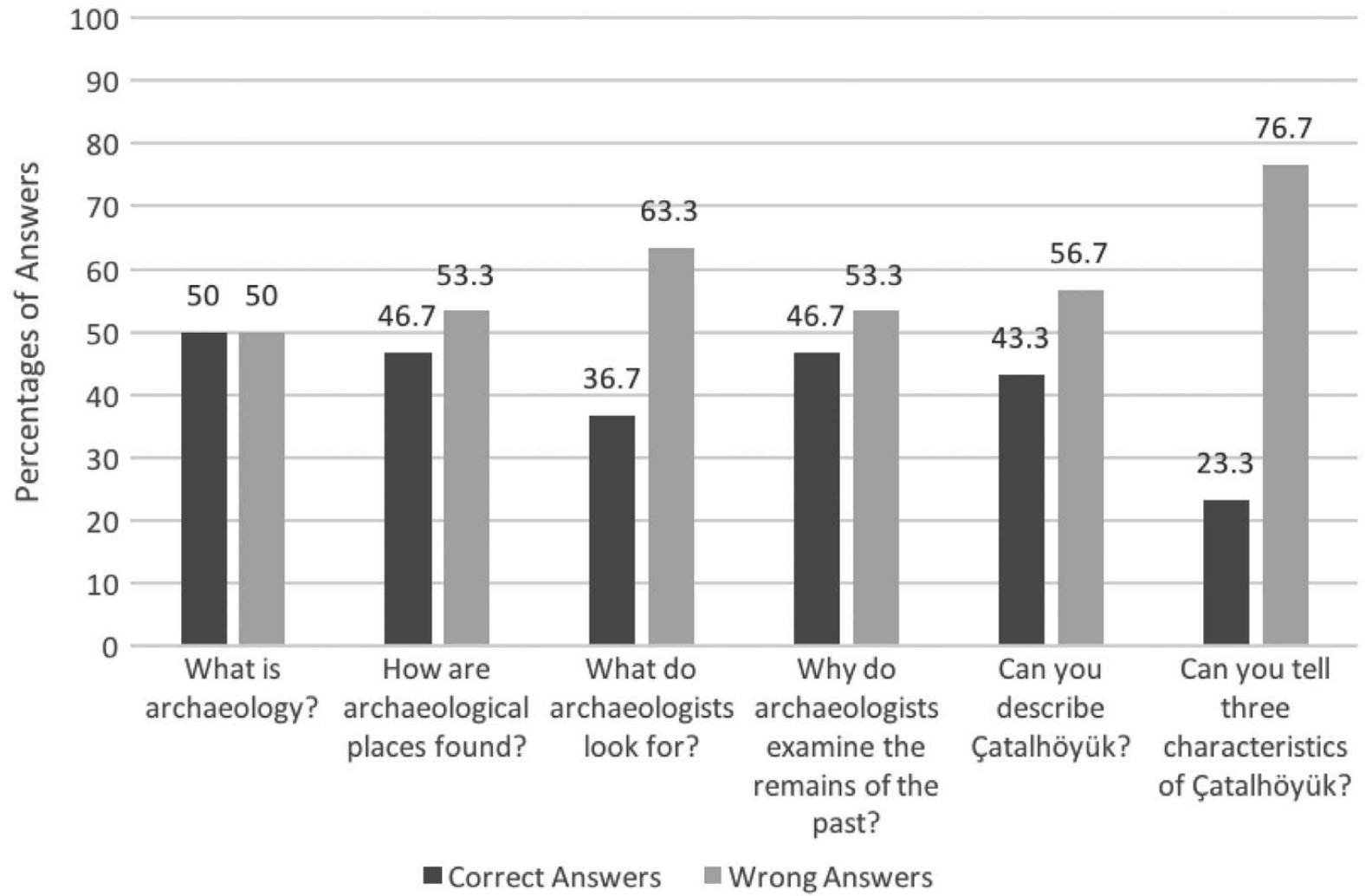

Figure 5. Frequencies of answers of the experimental group by percentage. 
The following two questions were open-ended and considered knowledge about Çatalhöyük: (5) Can you describe Çatalhöyük? and (6) Can you give three characteristics of Çatalhöyük? Interestingly, despite the fact that participants had attended the education day and that this information had been given, 56.7\% failed to describe Çatalhöyük. However, the most striking result came from the answers to question (6) as $76.7 \%$ of the participants failed describe any characteristics of Çatalhöyük (Figure 6).

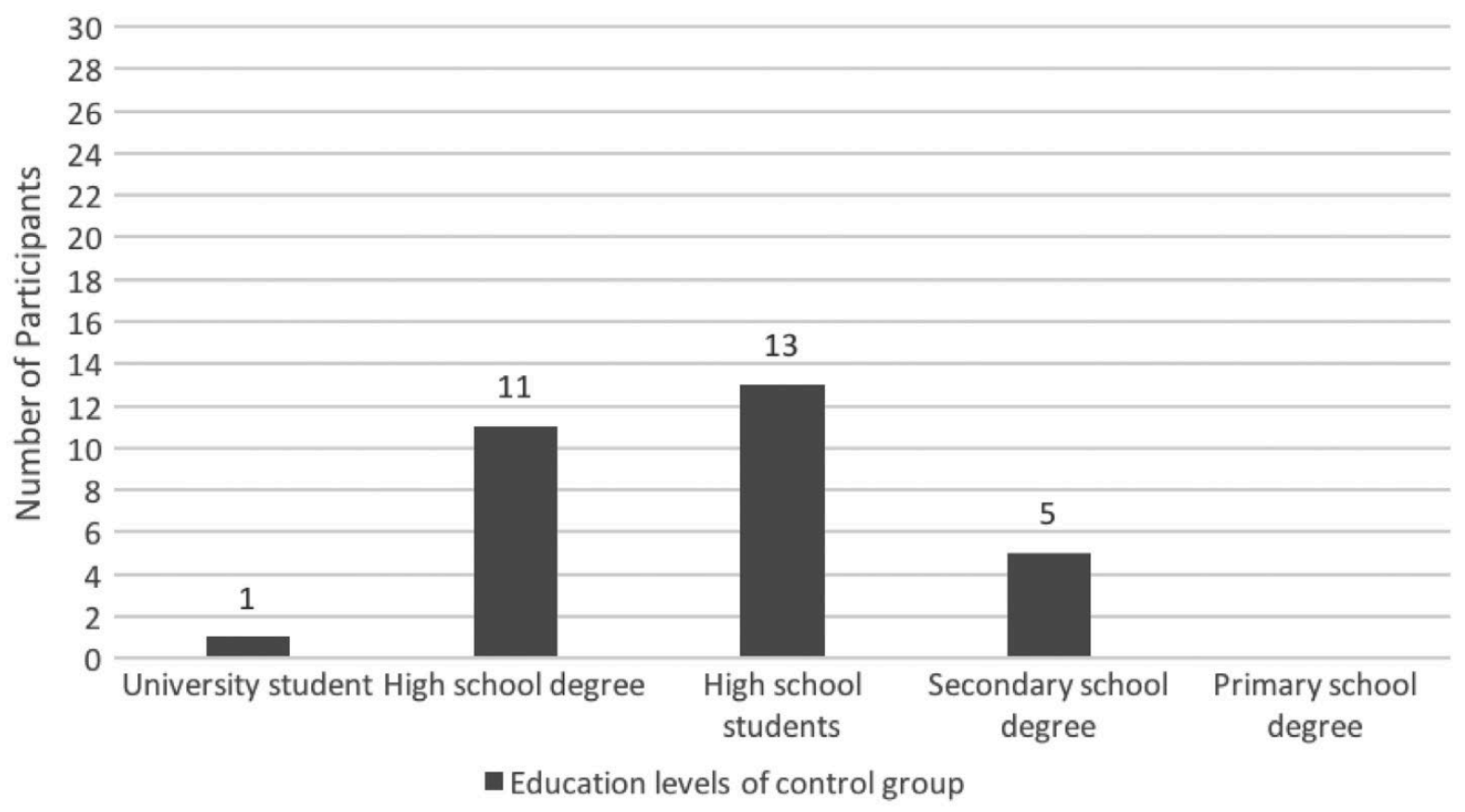

Figure 6. Education levels of control group

Table 1. Frequency table of responses to Question 8.

\begin{tabular}{lcc}
\hline What did you learn during the education day? & Frequency & Percent \\
\hline Don't remember at all & 23 & 76.67 \\
Remember detail & 3 & 10.0 \\
Remember generally & 4 & 13.33 \\
\hline
\end{tabular}

The rest of questions were open-ended and aimed to reveal whether they may have had any knowledge of Çatalhöyük before attending an education day, what they learned during the education programme (according to their recollection), and whether the education day had any impact on their views or heritage perception. For example, Question 7, 'What did you know about Çatalhöyük before attending the education programme?' like the previous questions, didn't get very informative responses; answers were mainly clichéd, e.g. 'ancient people lived there'. Most of the participants answered by saying, 'I had no knowledge at all'. Only a few participants responded to this question with very elaborate and accurate knowledge.

The main reason for the level of knowledge in those participants is not related to either the effectiveness of the education day nor formal education. The participants' social, political, economical and educational background prior to the survey exposed that participants who had good knowledge of Çatalhöyük were from families that worked at Çatalhöyük in the past, e.g. as labourers. This also shows the sustainable benefit of working in the archaeological sites (for more sustainable benefits see Orbaşl1 2013; Apaydin 2015). 
Question 8, 'What did you learn during the education day?' received a very low response level: 23 of the participants '[didn't] remember at all', 4 of them 'remember generally' and only 3 of them 'remember detail' (Table 1).

The study also aimed to expose whether the education programme had encouraged any curiosity in participants about the progress of the site's archaeology. They were asked: 'Have you visited Çatalhöyük since the education programme?' While sixteen participants stated that they had visited the site after education programme once or a few times, 14 of the participants stated that they had never visited the site after attending education programme (Table 2).

Another question was designed specifically to measure the impact of education programmes on the participants' heritage awareness, given that the aim of the education programme is to increase heritage awareness through Çatalhöyük, as mentioned above. Question 10 asked, 'Do you consider Çatalhöyük as part of your heritage or as a heritage site at all?' Similarly to previous questions, a dramatic response can also be seen from participants: only three of them stated that 'Çatalhöyük is part of my heritage'; fifteen of the participants stated that 'it is a heritage site but not ours'; the rest (12 participants) said 'it is not a heritage site for me at all' (Table 3). The second and third categories of this question indicate how Turkish formal education, which has strong nationalist and Islamic agendas influencing history education, influences people's perception. I have argued elsewhere (Apaydin 2016) that most locally educated students in Turkey have imposed on them an official history that only includes Turkish, Islamic and the Ottoman periods, and mostly excludes other histories such as the prehistoric or ancient past. This has been the case since the Turkish State was established in 1923. It would be quite beneficial here to discuss briefly the contents of the history textbooks in Turkish schools.

Table 2. Frequency table of responses to Question 9.

\begin{tabular}{lcc}
\hline Have you ever visited the site after the education programme? & Frequency & Percent \\
\hline Once or a few times & 16 & 53.3 \\
Never visited & 14 & 46.67 \\
\hline
\end{tabular}

Table 3. Frequency table of responses to Question 10.

\begin{tabular}{lcc}
\hline Do you consider Çatalhöyük as part of your heritage? & Frequency & Percent \\
\hline It is part of my heritage & 3 & 10.00 \\
It is a heritage but not ours & 15 & 50.00 \\
It is not heritage & 12 & 40.00 \\
\hline
\end{tabular}

Education has been a significant tool for Turkish nation state to transmit its ideology on to their citizens in order to consolidate its existence. Formal education, e.g. schools, is a very important route as it can reach large numbers of people. During the construction of the Turkish nation state, from the 1920s through 1940s, archaeology, heritage and history were given prominence (Atakuman 2008) in developing and later consolidating Turkish identity. All state institutions, as well as society as a whole, underwent a great transformation during the construction of the Turkish state after the collapse of the Ottoman Empire. Schools were transformed into a nationalist concept. The history textbooks were rewritten from a nationalistic perspective and they emphasised the Turkish past, making connections with older civilizations (Ersanl1 2003; Apaydin, forthcoming-a) in order to claim ownership rights to the lands, to claim how Turks spread civilisation to other parts of the world and to claim that Turks led many innovations in history. 
In following decades after the construction period, the focus of textbooks shifted and gave more importance to the Islamic periods, the Ottoman Empire and Turkish past, as well as the history of the modern Turkish Republic, which also helped to shape Turkish ideology and nationalism (see Apaydin 2015, 2016). In the twenty-first century Turkey, the content of history textbooks hasn't changed much. For instance, the national-official past (Turkish past, Islamic periods and the Ottoman Empire) are much more prominent than the prehistoric past and minority heritages. Thousands of years of history, starting with the Palaeolithic and Neolithic periods, are presented in only a few paragraphs. Minority heritages, such as that of the Greeks and Armenians, are completely neglected (Apaydin 2015, 2016). Therefore, it is not surprising that most of the participants neither recognise the site as 'their' heritage nor recognise it as a heritage site at all. This attitude is not unique to the participants of the survey; most communities in Turkey recognise material culture of the past as heritage but only if it is from the Turkish, Islamic and Ottoman periods (Apaydin 2016). This also shows how effective formal education is in shaping people's minds, worldviews and heritage perceptions.

Some of the responses from the experimental group clearly show the success and positive impact on some of the participants' heritage perceptions. They had clear and detailed knowledge of Çatalhöyük and archaeology in general, and a high awareness of the protection of heritage sites. However, the dramatically negative answers, particularly to Question 10, from the large number of participants who also attended education programme, show that generally, the Çatalhöyük education programme did not have a positive impact. To measure the effectiveness and to explore reasons for this, it is necessary to examine the responses from the control group (those who had never attended the Çatalhöyük education programmes).

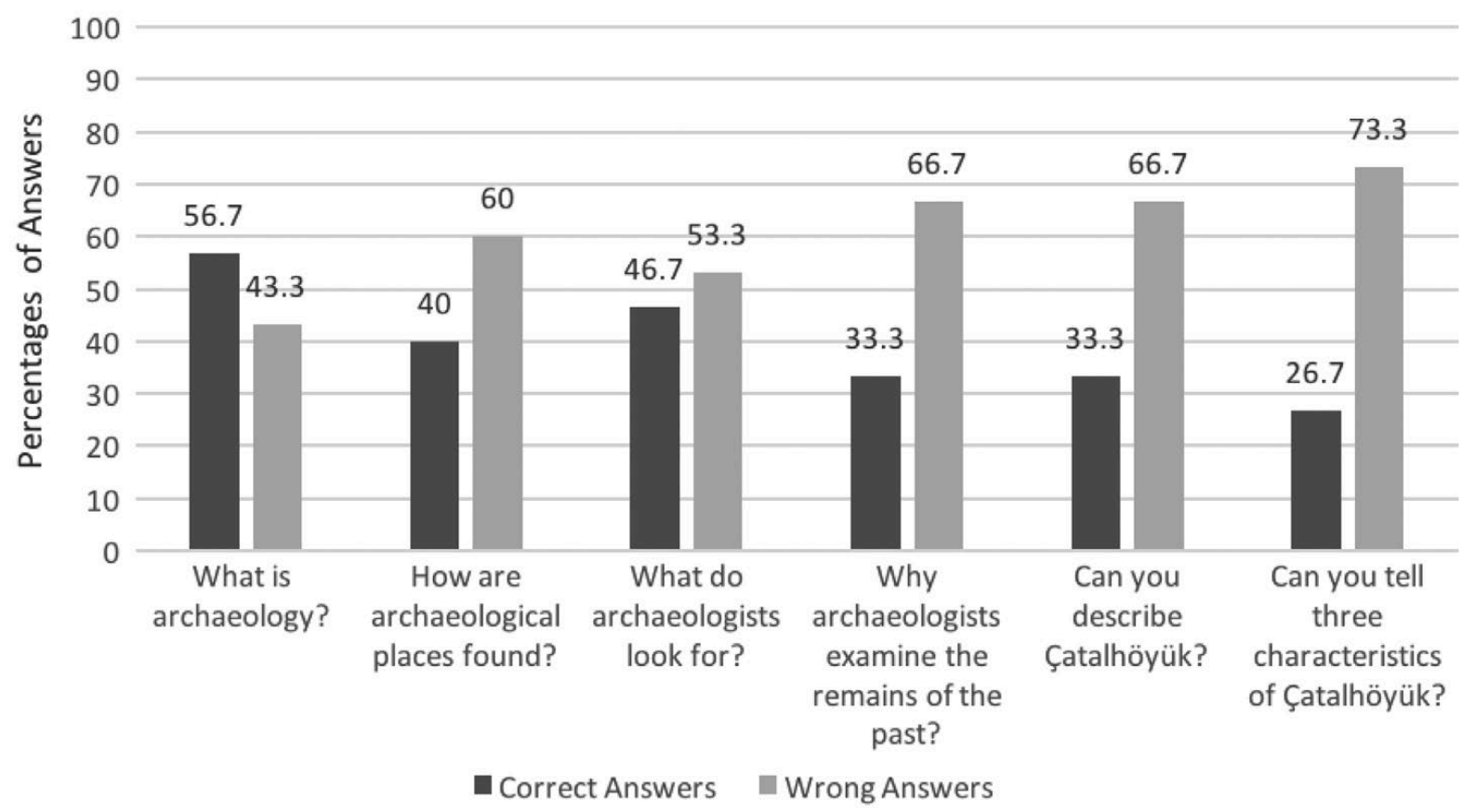

Figure 7. Frequencies for the answers of the group by percentage.

\section{Control group: people who never attended the education programmes}

An attempt was made to recruit participants for the control group from age, social, political and educational backgrounds similar to those of the experimental group. To this end, 
participants' backgrounds were clarified in unstructured interviews. The thirty participants included 17 females and 13 males (Figure 6).

The first questions of the questionnaire for the control group were exactly the same as for the experimental group. By asking the same questions, this study aimed to see if there were similarities and differences in responses between the two groups for comparison. Similarly to responses from the experimental group, while the first basic questions were answered well, with more correct answers, the correct answers dramatically decrease as the questions became more difficult (Figure 7). Excepting the response to the first question, the poor knowledge of the participants can be seen from the rest of the questions. The poor response once more shows the insufficiency of formal education and how it has failed to develop any knowledge of archaeology and heritage in students (see Apaydin 2016). Surprisingly, the control group, who had never attended the education programme, had a higher number of correct answers than the experimental group in response to the question asking for a description of three characteristics of Çatalhöyük.

Question 7 again was designed to see whether the presence of an internationally significant heritage site located near their homes had made people any more curious about heritage. Despite their proximity to the site, only 17 of them had visited (Table 4).

The ignorance, or in other words, the neglect of Çatalhöyük, a World Heritage Site, can be explained with the response to Question 8.

'Do you consider Çatalhöyük as part of your heritage?', which aims to assess heritage perception, received a similar response to the experimental group. The proportion of responses to this question ('it is part of my heritage', 'it is a heritage but not ours' or 'it is not heritage') was more or less identical to the experimental group (Tables 3 and 5). The justifications of people who answered this question with 'it is a heritage but not ours' or 'it is not a heritage' also show the strong influence of state ideology and official history (see Apaydin, forthcominga), which dominates schooling in Turkey. Most of the participants justified their response, saying something along the lines of: 'Çatalhöyük has no connection with Turkish, Islamic or Ottoman periods'. However, having said this, the role of informal education and the relationship between archaeologists and locals should not be discounted. These two factors may help to locals to overcome any biases towards Çatalhöyük.

Table 4. Frequency table of responses to Question 7.

\begin{tabular}{lcc}
\hline Have you ever visited Çatalhöyük? & Frequency & Percent \\
\hline Once or a few times & 17 & 56.63 \\
Never visited & 13 & 43.33 \\
\hline
\end{tabular}

Table 5. Frequency table of responses to Question 8.

\begin{tabular}{lcc}
\hline Do you consider Çatalhöyük as part of your heritage? & Frequency & Percent \\
\hline It is part of my heritage & 4 & 13.3 \\
It is a heritage but not ours & 12 & 40.00 \\
It is not a heritage & 14 & 46.67
\end{tabular}

The communication between site archaeologists with local communities is very significant as it leads to trust. For instance, at the archaeological site of Hattuşa, which is located in north central Turkey, systematic excavations of the Hittite site have been going on for over a hundred years, and the long years of personal efforts and good communications between archaeologists and local communities has led to high heritage awareness among the locals (see Apaydin 2015). 
Interestingly, the four people from the control group who consider Çatalhöyük as part of their heritage emphasised that it must be well protected, and explained their statement with considerable knowledge. For example, one participant responded, 'Çatalhöyük is the past of all humanity; the first settlers after hunting and gathering; a place where many things were invented such as domestication of animals and crops; it is also significant to protect it for a better future' [trans. from Turkish]. Formal education doesn't include the level of detailed information these participants had, and since they hadn't attended the Çatalhöyük education programme nor had any of their family members worked at the site, they must have derived this knowledge from different sources.

All in all, although none of the participants in the control group had attended Çatalhöyük education programmes, their responses to many questions and their comments and views were quite similar to those of the experimental group. The average age and backgrounds are also more or less similar. They have grown up in the same community and had the same formal education. Therefore, it can be argued that both groups' heritage perception is shaped firstly by formal education and secondly by the social environment that they live in. Furthermore, the few, ineffective community education programmes do not help to improve people's perceptions of heritage awareness in a positive way.

\section{Discussion and concluding comments: how can education programmes be effective?}

The aim of this survey was to test whether current heritage education programmes at Çatalhöyük are effective in providing support to increase heritage awareness for the protection and preservation of heritage sites. A second aim is to see how heritage education programmes can be effective. Although in recent years, bottom-up and participatory approaches (see Jameson 1997; Merriman 2004; Okamura and Matsuda 2011) have become more common, most of the archaeological attempts at increasing heritage awareness, including the Çatalhöyük education programme, have employed top-down approaches. These top-down approaches recall colonialist archaeology, as exemplified in the case of US archaeologists who had an imperialist relationship with the archaeology of Mexico (McGuire 2008, 9). In both cases, archaeologists who use a top-down approach reconstruct the material culture of the past and impose their version of knowledge on communities.

Regardless of the approach taken most projects have also neglected the social, political and economic backgrounds of the local communities in their education programmes and have also used similar methodologies for socially, ethnically, politically and economically different communities. As a result of not acknowledging these aspects during the design and practice, the archaeological education programmes have failed to reach their goal, which is the increase of heritage awareness and interest of individuals and communities in the protection and preservation of the heritage sites.

The Çatalhöyük education programme, indeed, perhaps all community archaeology projects, should be re-designed to recognise the perspectives and address the needs of the local communities as well as regional and national concerns. With this in mind, I suggest eight principles for heritage education programmes:

(1)The education programme of Çatalhöyük should analyse the archaeological and heritage content of Turkish textbooks. This is significant as formal education in Turkey 
is compulsory from primary to high school (Apaydin 2015). Therefore, every single individual goes through this process from an early age into adulthood, where his/her mind, worldview and heritage perception are shaped. Considering the content of formal education and the way in which heritage and archaeological materials are imposed on students, this would help enable the effective construction and function of community archaeology education programmes.

(2) As children are also part of the community, the socio-political, economic and educational backgrounds of the participants should be brought into consideration. This can be done with simple ethnographic research, including participant observations and interviews, around the villages of Çatalhöyük (and other archaeological sites). This is significant in two ways: first, every community has a different construction process as they all have different social and natural environments (Cohen 1985); and second, in countries such as in Turkey, the access to quality education differs according to people's economic circumstances.

(3) The pedagogical formation in children, the development of personality, and their perceptions and learning abilities should be taken account. The education programme should be designed and implemented by not only archaeologists, but also by educators who have a good knowledge of the pedagogical formation processes in children. This is significant because every child has different learning abilities at different ages, and therefore, different education programmes should be designed and presented for children who are at different learning levels. However, children should not be excluded from the realities of social-cultural and political context as they are also having 'ideological experience' (Pascoe 2010; Smith 2013, 107) of the past when they visit the heritage sites or museums. Children's interpretations reflect the current political context of which they are a part (see Jenkins 1998 for children's interpretation of culture and for children and cultural heritage, see Darian-Smith and Pascoe 2013). This is significant because interpretation of the material culture of the past is shaped by current political requirements (Wrestch 2002, 8; Smith 2013). Smith $(2013,108)$ points out that 'heritage is a performance in which individual and collective remembering and commemoration are central, and in which historical narratives and social and cultural values are continually re/created, arbitrated, affirmed or rejected'.

(4) In both formal and informal education, it is very common for teachers to transfer knowledge and for students to receive it (Freire 1993). Replacing this traditional approach with interactive learning may be more beneficial for both the students and the teachers. As knowledge is produced and ascribed to objects and monuments by people, and it is from them that archaeologists and heritage specialists can also learn about heritage perception and knowledge. Certain knowledge shouldn't be imposed upon and dictated to children by archaeologists or educators. Instead by taking into account their cultural, historical and personal context (Falk and Dierking 1992) and values, children should be offered a choice in what they would like to learn about and experience from an archaeological and heritage site. In this contextual model (Falk and Dierking 2000; Smith 2015) participants makes meaning from their own experience (Falk 2004; Smith 2015,462 ). While this avoids the issue of bias common in the top-down approach, it also provides support and enables participants to design their own education day 
For instance, ethnographic studies show the similarity between house building thousands of years ago at Çatalhöyük and the modern villages Çatalhöyük today. Mud brick houses were quite common in the region until recently (see Çekül 2012). Additionally, the region of Çatalhöyük is the largest farming area for wheat and other crops in Anatolia. It is also a major area for animal husbandry. The archaeological evidence at Çatalhöyük shows early domestication of crops and animals, which indicates continuity agricultural landscape. All villagers around Çatalhöyük are very familiar with, indeed some are experts at, mud brick houses or farming. Therefore, their knowledge and observations should be used to shape the education days as well. The Hackney Community Project (Museum of London Archaeology Service 2016b) provides an excellent model, as community archaeologists offered students the possibility of engaging with their local heritage by interpreting it themselves.

(5)The education programme should not only be restricted to the period during the excavation but should be expanded throughout the year. This could be made possible by training local people and by active collaboration with local schools, similar to the pioneering projects by Archaeology Sessions in Schools (Museum of London Archaeology Service 2016a). These initiatives actively collaborate with schools across London in order to provide an opportunity for students to understand the importance of the past and heritage.

(6) In most countries, including Turkey, the UK and other European countries, the focus of the education programme is to reach as many people as possible by increasing the number of participants. However, particularly in local areas, this should shift to focusing on a small number of people with more sustainable and continuous education programmes. Similarly, in the case of Çatalhöyük, instead of bringing students from all over the Konya plain, the education programme should focus only on the students in the nearby villages throughout the year.

(7) Children should have the opportunity to gain practical experience by taking part in excavations (instead of learning only through lectures). The Dig Manchester excavation at Northern Mill in the UK has successfully done this by including children as excavators (see Pye 2015). Activities, such as object making (e.g. making clay objects), should not be treated only as a game, but children should also be able to engage with the excavation finds. By touching the actual objects, they will feel the power of the object and therefore have the opportunity to shape their own knowledge (see Foucault 1977, 1979; Macdonald 1998). The community archaeology project at the Aimhigher and deserted mediaeval villages in the UK is a good example, as children could handle, in this instance, thirteenth century dated objects (see Knowles 2011).

(8) Communities in close proximity to the site should not be excluded from any stages of the management of the site and the project. The community archaeology project in Devon has proved that this is possible. More than 350 community members have been involved in 50 fieldwork surveys and have identified archaeological finds (see Hawken 2011). In some cases, although a place may have been active thousands of years ago and have no continuous cultural connection with the current community, the heritage site has an important place in the daily life of the local people; it is part of their landscape where memories have been ascribed over years and generations, and local people are its natural guardians (Pearson and Sullivan 1995). Therefore, the decisions regarding heritage sites should be made by taking into account the community's best 
interests. Archaeologists should place communities in the centre of the decision-making process and empower them to take control of decisions

\section{Acknowledgements}

The author wishes to thank community members for taking part in this study and Ian Hodder who is the director of Çatalhöyük Research Project for providing support. Author would also like to thank reviewers of this paper and the editor of International Journal of Heritage Studies for their great comments. 


\section{References}

Apaydin, V. 2015. "The Presentation of the Past: Pitfalls and Potentials-education and Archaeology, Heritage and Communities in Turkey-The Case Studies of Çatalhöyük, Ani and Hattuşa." Unpublished PhD thesis. University College London.

Apaydin, V. 2016. "Development and Re-configuration of Heritage Perception: History Textbooks and Curriculum in Turkey." AP Online Public Archaeology Journal. Vol. 6, 37-50.

Apaydin, V. 2017. Heritage Values and Communities: Examining Heritage Perceptions and Public Engagements. Journal of Eastern Mediterranean Archaeology and Heritage Studies. Vol-5, No: 3. 349-363.

Atakuman, C. 2008. "Cradle or Crucible: Anatolia and Archaeology in the Early Years of the Turkish Republic (1923-1938)." Journal of Social Archaeology 8: 214-235.

Brown, G., J. Bull, and M. Pendlebury. 2013. Assessing Student Learning in Higher Education. New York: Routledge.

Candan, A. 2007. "Developing Educational Programmes for Prehistoric Sites: The Çatalhöyük Case." In Mediterranean Prehistoric Heritage. Training, Education and Management, edited by I. Hodder and L. Doughty, 95-106. Cambridge: McDonald Institute for Archaeological Research.

Çatalhöyük Archive Report. 2011. Archive Reports 2011. Accessed February 15, 2015. http://www.catalhoyuk.com/

downloads/Archive_Report_2011.pdf

Çekül. 2012. Anadolu'da Kirsal Mimarlik [Rural Architecture in Anatolia]. Istanbul: Çekül Vakfı.

Cohen, A. 1985. The Symbolic Construction of Community. London: Routledge.

Copeland, T. 2004. "Interpretations of History: Constructing Pasts." In Education and Historic Environment, edited by D. Henson, P. Stone, and M. Corbishley, 33-41. London: Routledge.

Corbishley, M. 2004. "English Heritage Education: Learning to Learn From the Past." In Education and Historic Environment, edited by D. Henson, P. Stone, and M. Corbishley, 6773. London: Routledge.

Darian-Smith, K., and C. Pascoe, eds. 2013. Children, Childhood and Cultural Heritage. London: Routledge.

Davis, M. E. 2005. How Students Understand the Past. From Theory to Practice. New York: Altamira Press.

Dhanjal, S. 2008. "Archaeological Sites and Informal Education: Appreciating the Archaeological Process." Conservation and Management of Archaeological Sites 10 (1): 5263. 
Ersanlı, B. 2003. Iktidar ve Tarih. Türkiye'de "Resmi Tarih" Tezinin Oluşumu (1929-1937) [Power and History: The Construction of the "Official History" Thesis in Turkey (1929-1937)]. Istanbul: Iletişim Yayınları.

Falk, J. H. 2004. "The Director's Cut: Toward an Improved Understanding of Learning from Museums." Science Education 88: S83-S96.

Falk, J. H. 2005. "Free-choice Environmental Learning: Framing the Discussion." Environmental Education Research 11 (3): 265-280.

Falk, J. H., and L. D. Dierking. 1992. The Museum Experience. Washington, DC: Whalesback.

Falk, H. J. and L. D. Dierking. 1997. "School Field Trips: Assessing Their Long-term Impact." Curator: The Museum Journal 40 (3): 211-218.

Falk, J. H., and L. D. Dierking. 2000. Learning from Museums: Visitor Experiences and the Making of Meaning. Walnut Creek, CA: AltaMira.

Foucault, M. 1977. Discipline and Punish: The Birth of the Prison. Translated by A. Sheridan. London: Allen Lane.

Foucault, M. 1979. The History of Sexuality: An Introduction. Vol. 1. Translated by R. Hurley. London: Allen Lane.

Freire, P. 1993. Pedagogy of Oppressed. London: Routledge.

Hawken, S. 2011. "Community Archaeology Projects and Devon's Heritage: Recent Approaches and Challenges." In Community Archaeology. Themes, Methods and Practices, edited by G. Moshenska and S. Dhanjal, 110-114. Oxford: Oxbow Books.

Hein, E. G. 1998. Learning in the Museum. New York: Routledge.

Henson, D. 2004a. "Archaeology in Schools." In Education and Historic Environment, edited by D. Henson, P. Stone, and M. Corbishley, 23-32. London: Routledge.

Henson, D. 2004b. "Archaeology and Education, An Exercise in Constructing the Past." In Creació I divulgació de l'arqueologia i de la història [Communicating the Past. Creation and Outreach of Archaeologhy and History], P. Gonzalez Comunicar el passat, 5-16. Barcelona: Universitat Autònoma de Barcelona.

Henson, D. 2011. "Does Archaeology Matter?" In Community Archaeology. Themes, Methods and Practices, edited by G. Moshenska and S. Dhanjal, 120-127. Oxford: Oxbow Books.

Hodder, I., ed. 1996. On the Surface: Çatalhöyük 1993-95. Cambridge: McDonald Institute for Archaeological Research; London: British Institute of Archaeology Ankara. 
Hodder, I., ed. 2000a. Towards Reflexive Method in Archaeology: The Example at Çatalhöyük. Cambridge: McDonald Institute for Archaeological Research.

Hodder, I. 2000b. "Developing a Reflexive Method in Archaeology." In Towards Reflexive Method in Archaeology: The Example at Çatalhöyük, edited by I. Hodder, 3-14. Cambridge: McDonald Institute for Archaeological Research.

Hodder, I., and L. Doughty, eds. 2007. Mediterranean Prehistoric Heritage. Training, Education and Management. Cambridge: University of Cambridge, McDonald Institute for Archaeological Research.

Holmes, J. A. 2011. "Informal Learning: Student Achievement and Motivation in Science through Museum-based Learning." Learning Environments Research 14: 263-277.

Jameson, J. H., ed. 1997. Presenting Archaeology to the Public. Digging for Truths. Walnut Creek, CA: Altamira Press.

Jenkins, H., ed. 1998. The Children Culture Reader. New York: New York University Press.

Keskin, F., and O. M. Önen. 2012. Appropriate Investment Areas for the Konya Region. Konya: Konya Chamber of

Commerce, Inci Ofset. Accessed January 14, 2014. http://www.kto.org.tr/d/file/appropriateinvestment-areas-forthekonya-province.pdf

Knowles, J. 2011. "Aimhigher and Deserted Medieval Villages." In Community Archaeology. Themes, Methods and Practices, edited by G. Moshenska and S. Dhanjal, 63-71. Oxford: Oxbow Books.

Macdonald, S. 1998. "Exhibitions of Power and Powers of Exhibition: An Introduction to the Politics of Display." In The Politics of Display Museums, Sciences, Culture, edited by S. Macdonald, 1-21. London: Routledge.

McGuire, R. H. 2008. Archaeology as Political Action. Berkeley: University of California Press.

Mellaart, J. 1967. Çatal Hüyük. London: Thames \& Hudson.

Merriman, N., ed. 2004. Public Archaeology. London: Routledge.

Moshenska, G., and S. Dhanjal. 2011. "Introduction: Thinking about, Talking about, and doing Community Archaeology." In Community Archaeology. Themes, Methods and Practices, edited by G. Moshenska and S. Dhanjal, 1-5. Oxford: Oxbow Books.

Museum of London Archaeology Service. 2016a. "Research and Community." Museum of London. Accessed January 15, 2016. http://www.mola.org.uk/community-archaeology 
Museum of London Archaeology Service. 2016b. "Hackney Community Project." Museum of London. Accessed January 15, 2016. http://www.mola.org.uk/projects/hackney-communityproject

Nadelson, L. S., and R. Jordan. 2012. "Student Attitudes Toward and Recall of Outside Day: An Environmental Science Field Trip." The Journal of Educational Research 105 (3): 220-231.

Okamura, K., and A. Matsuda. 2011. "Introduction: New Perspective on Global Public Archaeology." In New Perspectives in Global Public Archaeology, edited by K. Okamura and A. Matsuda, 1-16. London: Springer.

Oppenheim, A. N. 1992. Questionnaire Design, Interviewing and Attitude Measurement. London: Continuum.

Orbaşlı, A. 2013. "Archaeological Site Management and Local Development." Conservation and Management of Archaeological Sites 15 (3-4): 237-253.

Pascoe, C. 2010. "The History of Children in Australia: An Inter-disciplinary Historiography." History Compass 8 (10): 142-164.

Pearson, M., and S. Sullivan. 1995. Looking after Heritage Places. Carlton: Melbourne University Press.

Piscitelli, B., and D. Anderson. 2001. "Young Children's Perspectives of Museums Settings and Experiences." Museum Management and Curatorship 19 (3): 269-282.

Planel, P. 1994. "New Archaeology, New History-When will they Meet? Archaeology in English Secondary Schools." In The Excluded Past: Archaeology in Education, edited by P. Stone and R. MacKenzie, 271-279. London: Routledge.

Pye, C. 2015. "Keeping it Going: Education as an Agent for Continuity." In Archaeology for All. Community Archaeology in the Early 21st Century: Participation, Practice and Impact, edited by M. Nevell and N. Redhead, 100-104. Leicester: Centre for Applied Archaeology, University of Salford.

Shankland, D. 1999. Islam and Society in Turkey. Cambridgeshire: The Eothen Press.

Shankland, D. 2004. "The Universal and the Local at Çatalhöyük, Turkey." In Archaeology, Anthropology and Heritage in the Balkans and Anatolia: The Life and Times of F. W. Hasluck, 1878-1920, edited by D. Shankland, 465-480. Istanbul: The Isis Press.

Simpson, F. 2011. "Shoredicth Park Community Excavation: A Case Study." In Community Archaeology. Themes, Methods and Practices, edited by G. Moshenska and S. Dhanjal, 115119. Oxford: Oxbow Books.

Smith, L. 2006. Uses of Heritage. London: Routledge. 
Smith, L. 2010. "Ethics or Social Justice? Heritage and the Politics of Recognition." Australian Aboriginal Studies 2: 60-68.

Smith, L. 2012. "The Cultural 'Work' of Tourism." In The Cultural Moment of Tourism, edited by L. Smith, E. Waterton and S. Watson, 210-234. London: Routledge.

Smith, L. 2013. "Taking the Children. Children, Childhood and Heritage Making." In Children, Childhood and Cultural Heritage, edited by K. Darian-Smith and C. Pascoe, 107-125. London: Routledge.

Smith, L. 2015. "Theorizing Museum and Heritage Visiting." In The International Handbooks of Museum Studies: Museum Theory, edited by A. Witcomb and K. Message, 460-484. London: Wiley.

Tzibazi, V. 2014. "Primary Schoolchildren's Experiences of Participatory Theatre in a Heritage Site." Education 42 (5):

498-516.

Wrestch, J. V. 2002. Voices of Collective Remembering. Cambridge: Cambridge University Press. 